\title{
Primary sector waste indicators for regional planning
}

\author{
E. Cifrian, L. Pérez, E. Dosal, J. Viguri \& A. Andrés \\ Chemical Engineering Department, University of Cantabria, Spain
}

\begin{abstract}
Decisions are made based on information of different kinds and several tools have been developed to facilite the inclusion of environmental aspects in decision-making. One of these tools is the indicators that have become a vital component of environmental impact assessments and "state of the environmental" reporting.

In Cantabria, a northern Spanish region, a specific set of indicators has been developed to monitor the degree of implementation of waste policies recently adopted in the region, identified in the Cantabria Regional Waste Plan 20102014. This Regional Planning covers all waste streams generated: There is a Regional Waste Plan developed through four Sectorial Waste Plans on: (i) Primary Sector and Sanitary Waste; (ii) Industrial, Construction and Demolition, and Mining Waste; (iii) Special Waste, and (iv) Municipal Waste.

At the present time, the primary sector waste flows in Cantabria are outstanding, since it is a region where the primary sector is one of the driving forces of the economy together with the tourism. The $86 \%$ of municipalities are classified as rural or semirural, and there, it is producing a large rural development from traditional craft production to intensive farms in which waste management is becoming a problem.

In this work the methodology developed by European Environmental Agency has been used as a starting point in developing a set of Specific Indicators on the primary sector waste. Eleven indicators have been developed to evaluate the generation and management of forest, agricultural, livestock and food industry waste. These indicators allow not only monitoring the primary sector waste management, but also they highlight the precarious situation in relation to knowledge of actions undertaken in the sector in relation to their waste and with
\end{abstract}


the information flows. Therefore, in this paper the analysis of difficulties for management the available information has been carried out.

Keywords: environmental indicators, regional planning, rural development, waste management, primary sector.

\section{Introduction}

The region of Cantabria, in the north of Spain, has been traditionally an agricultural region. Due to various factors, including changes in production practices, this sector is currently in recession, but it is still significant in the region. The primary sector can impact on air quality, soil and water. Its activities generate waste streams from different sources: livestock, agriculture, forestry and food industry. These streams have a significant impact on the land and the rural landscape. The increased generation of these waste streams is caused by factors such as intensification (separating agriculture from livestock and increasing production), concentration (getting closer to consumer points) and specialization (focusing on few products).

Therefore, the development of the sector and the introduction of hazardous materials in the production highlight the need to manage properly these waste streams.

\subsection{Sectorial waste plan}

Different European and National regulations on waste implemented in last years and the elaboration of Cantabria Regional Waste Plan 2006-2010 were the context to create Sectorial Waste Sector Plans. They must be the regional reference for minimizing, reuse, recycling, energy recovery and disposal of waste in Cantabria, fixing specific management objectives for several waste streams (BOC [1]):

- Primary sector, health and veterinary services waste.

- Industrial, construction and demolition and mining waste.

- Special waste.

- Municipal waste.

\subsection{Development of indicators sets}

Global progress towards sustainable development has originated the adoption of different sets of sustainability indicators which serve to provide information on specific environmental problems as a tool in decision-making (Aguirre [2]).

The European Environment Agency (2005) defines the concept of indicator as a measure, generally quantitative, that can be used to illustrate and communicate complex phenomena in a simple way, including trends and progress over time (Smeets and Waterings [3]). Environmental indicators are generally used for the following key objectives (Aguirre [2]):

- Provide information of environmental problems.

- Summarize large amount of information in relevant indicators simplifying and harmonizing reports at various scales or levels. 
- Monitor policies and setting priorities, identifying key factors of pressure on the environment.

- Assess trends in relation to objectives and help define new ones.

- Contribute to raising public managers on environmental issues.

This study focuses on the evaluation of the Primary Sector Regional Waste Plan through development of indicators. For it, a exhaustive compilation of all available information related to primary sector waste is necessary, analyzing all sources, assessing their characteristics through "scoring" to show the difficulties for management the information and proposing future strategies through SWOT analysis.

\section{Methodology}

In order to obtain the indicators, a methodology has been developed. It consists of five stages: synthesis, development, application, interpretation and SWOT analysis (Cifrian et al. [4]). This methodology is shown on figure 1.

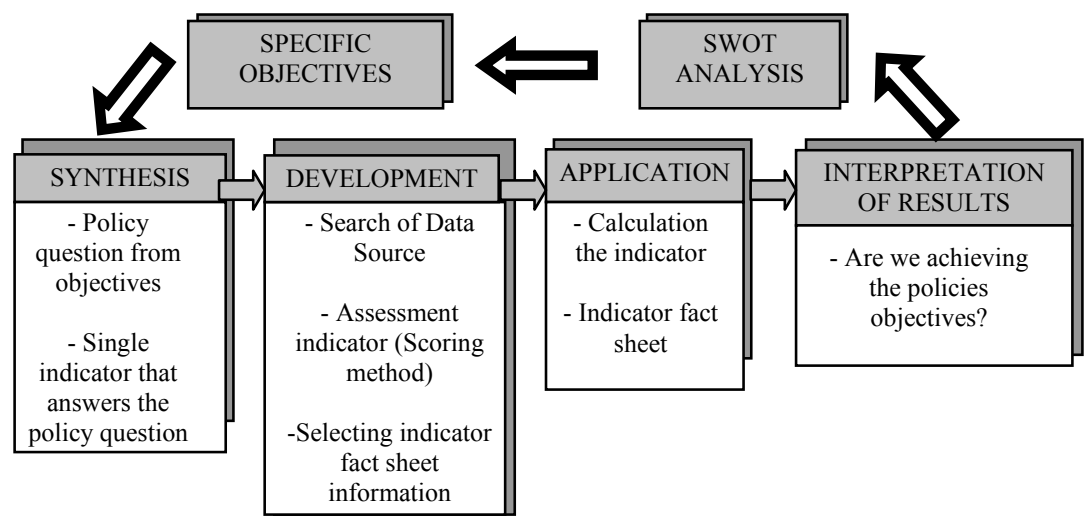

Figure 1: Methodology developed for obtaining the set of indicators.

Each stage consists of:

a) Synthesis: Indicators selection begins raising a policy question related to a group of objectives. A single indicator that answers the question is obtained.

b) Development: After establishing the indicators, a search of data sources is required. For this, it is necessary to make a preliminary analysis of all variables and data required of each indicator and develop a catalogue of them.

Once developed the catalogue of sources, the potencial of development of these indicators are evaluated. This assessment shows the weaknesses associated with lack of available data and it is based on the theoretical conditions to be met by the indicators:

- Relevant: Related to goals, objectives and priorities.

- Reliable: Based on complete and accurate data.

- Functional: Useful in decision-making.

- Quantifiable: Measurable with relative ease.

- Comparable: Obtained at different spatial and temporal scales. 
Applying these criteria to define some questions (or sub-criterias) and providing a score depending on the answers, the viability and feasibility of the indicators can be labelled. Criteria, subcriteria and scores are shown in Table 1.

Table 1: $\quad$ Criteria used to evaluate indicators.

\begin{tabular}{|c|c|c|}
\hline CRITERIA & Sub-criteria & Scoring \\
\hline Relevant & $\begin{array}{l}\text { Is the indicator related linked to policy targets, } \\
\text { objectives or legislation? }\end{array}$ & $\begin{array}{l}0=\text { No } \\
1=\text { Yes, indirectly } \\
2=\text { Yes, directly }\end{array}$ \\
\hline Credible & Are data complete and accurate? & $\begin{array}{l}0=\text { No data record } \\
1=\text { Data obtained from } \\
\text { various sources } \\
2=\text { Data obtained from a } \\
\text { single source }\end{array}$ \\
\hline \multirow[t]{2}{*}{ Functional } & $\begin{array}{l}\text { Could the indicator provide clear and } \\
\text { understandable information? }\end{array}$ & $\begin{array}{l}0=\text { No } \\
1=\text { Interpretation requires } \\
\text { prior knowledge } \\
2=\text { Direct interpretation }\end{array}$ \\
\hline & $\begin{array}{l}\text { Could the indicator provide information that is } \\
\text { useful to policy decision? }\end{array}$ & $\begin{array}{l}0=\mathrm{No} \\
2=\mathrm{Yes}\end{array}$ \\
\hline \multirow[b]{2}{*}{ Quantifiable } & Are data easily accesible? & $\begin{array}{l}0=\text { No } \\
2=\text { Yes }\end{array}$ \\
\hline & $\begin{array}{l}\text { Is the indicador based on direct or indirect } \\
\text { measurements? }\end{array}$ & $\begin{array}{l}0=\text { No data record } \\
1=\text { Estimates } \\
2=\text { Direct measurement }\end{array}$ \\
\hline \multirow{2}{*}{ Comparable } & Time series are available? & $\begin{array}{l}0=\text { No data record } \\
1=\text { No, only data points } \\
2=\text { Complete data record }\end{array}$ \\
\hline & $\begin{array}{l}\text { Is the indicator linked with other indicators } \\
\text { from the same Plan? }\end{array}$ & $\begin{array}{l}0=\text { No } \\
1=\text { Qualitative link } \\
2=\text { Quantitaive link }\end{array}$ \\
\hline
\end{tabular}

Sources: (EEA [6]), (Viikari [7])

Table 2: $\quad$ Interpretation of results: Icons.

If the indicator has a good trend, reaching the objectives.

If data shows positive trends, approaching the targets, but not enough to get them.

If data trend is away from the target.

No data available or there is insufficient data to observe a trend.

After this evaluation, it is selected the indicator fact sheet information, containing the main characteristics, those that justify the choice of the indicator. It also specifies the characteristics of its data or the calculation method, its variables and the sources to obtain the information and how to manage it.

c) Application: In this step, it is necessary to calculate specific variables such as rates or ratios. The progress over time is represented graphically and, then, an analysis is performed to define the trends. Both are included in the fact sheet which also includes information that can help to give an overview of the situation such as applicable laws or action lines. 
d) Interpretation of results: The results obtained must be compared with the proposed objectives in the Sector Plan. The level of achievement is represented by icons (Table 2).

e) SWOT Analysis: SWOT is a classic strategic analysis tool for strategic management. It is the strategic adaptation between resources and capacity. SWOT integrates internal resources of an indicator (strengths/weakness) and external environment analysis (opportunities/threats) (Yang [8]).

Table 3: $\quad$ Indicators associated with the proposed objectives.

\begin{tabular}{|c|c|}
\hline OBJECTIVES & INDICATOR \\
\hline - Adaptation of manure storage facilities. & $\begin{array}{c}\text { 1. DEGREE OF } \\
\text { ADAPTATION OF MANURE } \\
\text { STORAGE FACILITIES } \\
\end{array}$ \\
\hline $\begin{array}{l}\text { - Carrying out educational campaigns on the proper use } \\
\text { of manure as fertilizer and agri-food, agricultural and } \\
\text { livestock waste management. } \\
\text { - Favouring the implementation of the Code of Good } \\
\text { Agricultural Practice of Good Agricultural and } \\
\text { Environmental Conditions and Statutory Management } \\
\text { Requirements. }\end{array}$ & $\begin{array}{c}\text { 2. LEVEL OF } \\
\text { DEVELOPMENT OF } \\
\text { EDUCATIONAL } \\
\text { CAMPAIGNS OF PRIMARY } \\
\text { SECTOR WASTE }\end{array}$ \\
\hline $\begin{array}{l}\text { - Getting participation of economic operators in waste } \\
\text { management. } \\
\text { - Establishing monitoring mechanisms to provide } \\
\text { reliable and comprehensive information. }\end{array}$ & $\begin{array}{l}\text { 3. DEGREE OF ECONOMIC } \\
\text { OPERATORS } \\
\text { PARTICIPATION ON THE } \\
\text { WASTE MANAGEMENT }\end{array}$ \\
\hline - Increasing the use of biodegradable plastic. & $\begin{array}{l}\text { 4. LEVEL OF USE OF } \\
\text { BIODEGRADABLE } \\
\text { PLASTICS }\end{array}$ \\
\hline $\begin{array}{l}\text { - Minimizing the generation of phytosanitary packaging } \\
\text { waste. }\end{array}$ & $\begin{array}{l}\text { 5. LEVEL OF GENERATION } \\
\text { OF PHYTOSANITARY } \\
\text { PACKAGING WASTE }\end{array}$ \\
\hline $\begin{array}{l}\text { - Having enough land to value manure, or increasing its } \\
\text { territorial base. } \\
\text { - Improvement of the agronomic potential of manure. }\end{array}$ & $\begin{array}{l}\text { 6. RATE OF USEFUL LAND } \\
\text { TO REUSE THE MANURE }\end{array}$ \\
\hline $\begin{array}{l}\text { - Reusing } 100 \% \text { cheese whey. } \\
\text { - Adjustment rules of the agri-food waste. } \\
\text { - Establishing monitoring mechanisms to provide } \\
\text { reliable and comprehensive information. }\end{array}$ & $\begin{array}{l}\text { 7. RATE OF WASTE } \\
\text { RECYCLING IN FOOD } \\
\text { INDUSTRY }\end{array}$ \\
\hline $\begin{array}{l}\text { - Adjustment rules for managing livestock and } \\
\text { agricultural waste. } \\
\text { - Implement the management model for cleaning and } \\
\text { disinfecting containers and plastics for agricultural use. }\end{array}$ & $\begin{array}{l}\text { 8. DEGREE OF } \\
\text { IMPLEMENTATION OF } \\
\text { MANAGEMENT MODELS }\end{array}$ \\
\hline $\begin{array}{l}\text { - Increasing recovery rate of phytosanitary packaging } \\
\text { waste. }\end{array}$ & $\begin{array}{l}\text { 9. RATE OF RECOVERY OF } \\
\text { PHYTOSANITARY } \\
\text { PACKAGING WASTE }\end{array}$ \\
\hline $\begin{array}{l}\text { - Establishing monitoring mechanisms to provide } \\
\text { reliable and comprehensive information. } \\
\text { - Increasing the recovery of residual forest biomass }\end{array}$ & $\begin{array}{l}\text { 10. RATE OF RECOVERY } \\
\text { OF RESIDUAL FOREST } \\
\text { BIOMASS } \\
\end{array}$ \\
\hline $\begin{array}{l}\text { - Increasing the energy production from residual forest } \\
\text { biomass. } \\
\text { - Promoting the use of pellets as an energy source. }\end{array}$ & $\begin{array}{l}\text { 11. RATE OF ENERGY } \\
\text { PRODUCTION FROM } \\
\text { RESIDUAL FOREST } \\
\text { BIOMASS } \\
\end{array}$ \\
\hline
\end{tabular}


Table 4: Catalogue of data sources in the primary sector at different levels.

\begin{tabular}{|c|c|c|c|c|c|c|}
\hline \multirow[b]{2}{*}{ లె } & \multirow[b]{2}{*}{ 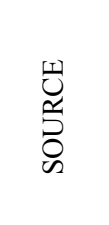 } & \multicolumn{5}{|c|}{ TYPE OF DATA } \\
\hline & & 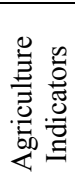 & 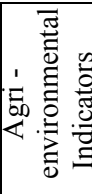 & 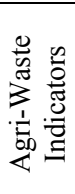 & 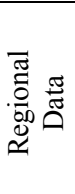 & 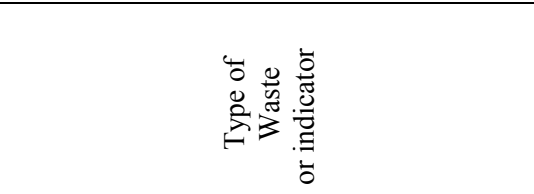 \\
\hline \multirow{3}{*}{ 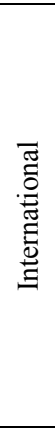 } & $\begin{array}{l}\text { EURO } \\
\text { STAT }\end{array}$ & SD & SD & SD & - & $\begin{array}{l}\text { Manure storage facilities } \\
\text { Farmers training level } \\
\text { Organics crop area }\end{array}$ \\
\hline & EEA & SD & SD & - & - & $\begin{array}{l}\text { Fertilizer consumption } \\
\text { Area of organic farming } \\
\text { Intensity of agriculture }\end{array}$ \\
\hline & OECD & SD & SD & - & - & $\begin{array}{l}\text { Agriculture production } \\
\text { Area harvested } \\
\text { Management of Water Resources in } \\
\text { Agriculture } \\
\text { Intensity of use of forest resources } \\
\end{array}$ \\
\hline \multirow{3}{*}{ 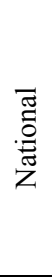 } & INE & SD & SD & PS & SD & $\begin{array}{l}\text { Waste generated in Agriculture, livestock, } \\
\text { hunting and forestry }\end{array}$ \\
\hline & MMA & SD & SD & - & SD & $\begin{array}{l}\text { Fertilizer consumption } \\
\text { Area of organic farming } \\
\text { Environmental efficiency of agriculture } \\
\text { Number of cattle }\end{array}$ \\
\hline & SIG & - & - & SD & SD & $\begin{array}{l}\text { Generation of phytosanitary packaging } \\
\text { waste }\end{array}$ \\
\hline \multirow[b]{3}{*}{ 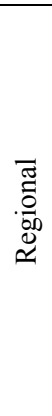 } & ICANE & SD & - & - & SD & $\begin{array}{l}\text { Number of cattle } \\
\text { Distribution of the surface } \\
\text { Organic production }\end{array}$ \\
\hline & RG & SD & - & - & SD & $\begin{array}{l}\text { Number of cattle } \\
\text { Economic aids to agricultural sector }\end{array}$ \\
\hline & CIFA & - & - & PS & PS & $\begin{array}{l}\text { Studies and treatment of effluents and } \\
\text { waste from cattle farms. } \\
\text { Study of serum production in Cantabria, } \\
\text { characterization, preservation and pre- } \\
\text { treatment. } \\
\text { Status and prospects for management of } \\
\text { whey generated in Cantabria. }\end{array}$ \\
\hline
\end{tabular}

Time coverage: Series of Data over time (SD) or Particular Studies (PS);

Sources: European Environmental Agency (EEA [9]); Organisation for Economic Co-operation and Development (OECD [10]); Spanish Institute of Statistics (INE [11]); Ministry of Environment of Spain (MMA [12]); Integrated Management Systems (SIG [13]); Institute of Statistics of Cantabria (ICANE [14]); Department of Rural Development, Livestock, Fisheries and Biodiversity of the Regional Government (RG); Center for Agricultural Research and Training (CIFA [15]).

\section{Results and discussion}

The synthesis step was applied with the objectives proposed in the Primary Sector Regional Waste Plan. Then, eleven indicators have been proposed, which are shown in Table 3. 
In order to develop indicators there is a need to find quantitative and qualitative information on the primary sector waste and contribute to the possible improvement of the management of this sector in the region of Cantabria. So first, a literature search of previous studies is required as an aid to focus the local problems. For that, it is necessary to elaborate a catalogue of the sources that manage data of the primary sector waste. Table 4 shows the major studios, projects, research and sources of data on waste managed by different agencies on different geographic levels.

After this, the indicators were evaluated based on scoring method. The results of each indicator are included in table 5. The selected criteria have non automatic function to determine the feasibility of the indicators. Instead, provide the framework for asking questions and warn of the various properties of the indicators (Kurtz [16]). However, this evaluation allows determine the potential development of these indicators. That is, four of the indicators obtain more than 10 points, so these indicators have a high development potential. The other indicators obtained a score below 10 points, and therefore its development is more complex and will take a long term because the necessary data records should be created.

The four most potential indicators, Level of use of biodegradable plastics, Level of generation of phytosanitary packaging waste, Rate of useful land to reuse the manure and Rate of recovery of phytosanitary packaging waste, have already been developed and they are detailed in tables $6,7,8$ and 9 respectively.

Table 5: $\quad$ Evaluation of indicators based of scoring method.

\begin{tabular}{|c|c|c|c|c|c|c|c|c|c|c|c|c|}
\hline \multirow{2}{*}{ CRITERIA } & \multirow{2}{*}{ Sub-criteria } & \multicolumn{11}{|c|}{ INDICATORS } \\
\hline & & 1 & 2 & 3 & 4 & 5 & 6 & 7 & 8 & 9 & 10 & 11 \\
\hline Relevant & $\begin{array}{l}\text { Is the indicator related } \\
\text { linked to policy targets, } \\
\text { objectives or legislation? }\end{array}$ & 2 & 2 & 2 & 2 & 2 & 2 & 2 & 2 & 2 & 2 & 2 \\
\hline Credible & $\begin{array}{l}\text { Are data complete and } \\
\text { accurate? }\end{array}$ & 0 & 0 & 0 & 2 & 2 & 1 & 0 & 0 & 2 & 0 & 0 \\
\hline \multirow[b]{2}{*}{ Functional } & $\begin{array}{l}\text { Could the indicator provide } \\
\text { clear and easy information? }\end{array}$ & 2 & 1 & 1 & 2 & 1 & 2 & 2 & 1 & 2 & 2 & 2 \\
\hline & $\begin{array}{l}\text { Could the indicator provide } \\
\text { information that is useful to } \\
\text { policy decision? }\end{array}$ & 2 & 2 & 2 & 2 & 2 & 2 & 2 & 2 & 2 & 2 & 2 \\
\hline \multirow[b]{2}{*}{ Quantifiable } & Are data easily accessible? & 0 & 0 & 0 & 2 & 2 & 2 & 0 & 0 & 2 & 0 & 0 \\
\hline & $\begin{array}{l}\text { Is the indicator based on } \\
\text { direct or indirect } \\
\text { measurements? }\end{array}$ & 0 & 0 & 0 & 1 & 1 & 1 & 0 & 0 & 2 & 0 & 0 \\
\hline \multirow{3}{*}{ Comparable } & Time series are available? & 0 & 0 & 0 & 1 & 2 & 2 & 0 & 0 & 2 & 0 & 0 \\
\hline & $\begin{array}{l}\text { Is the indicator linked with } \\
\text { other indicators from the } \\
\text { same Plan? }\end{array}$ & 1 & 1 & 0 & 0 & 1 & 1 & 0 & 1 & 1 & 2 & 2 \\
\hline & SCORE & 7 & 6 & 5 & 12 & 13 & 13 & 6 & 6 & 15 & 8 & 8 \\
\hline
\end{tabular}


Table 6: $\quad$ Factsheet information for the indicator 4 .

\begin{tabular}{cl}
\hline I4: LEVEL OF USE OF BIODEGRADABLE PLASTICS \\
\hline Description & $\begin{array}{l}\text { This indicator is based on the use of biodegradable plastic by farmers in } \\
\text { Cantabria compared to conventionally used plastics. }\end{array}$ \\
\hline $\begin{array}{c}\text { Environmental } \\
\text { relevance }\end{array}$ & $\begin{array}{l}\text { Conventional plastics are polymers that persist in nature for long periods of time } \\
\text { and generate large amounts of waste. For this reason it is proposed as a viable } \\
\text { alternative the use of biodegradable plastics. }\end{array}$ \\
\hline Data sources & $\begin{array}{l}\text { Department of Rural Development, Livestock, Fisheries and Biodiversity of the } \\
\text { Regional Government of Cantabria }\end{array}$ \\
\hline $\begin{array}{c}\text { Methodology of } \\
\text { calculation }\end{array}$ & $\begin{array}{l}\text { The use of conventional plastics is estimated from the number of bales used for } \\
\text { ensiling of forage in Cantabria because this use is the largest volume of plastics } \\
\text { consumed in the region. The use of plastics is estimated around 200,000 bales } \\
\text { annually with an average weight of 0.70 kg per bale. }\end{array}$ \\
\hline $\begin{array}{l}\text { Progress over time } \\
\text { Data has been remained stable in recent years: } \\
\text { CONVENTIONAL PLASTICS USE (Tonnes): 140 } \\
\text { BIODEGRADABLE PLASTICS USE (Tonnes): } 0\end{array}$ \\
\hline Interpretation of \\
results
\end{tabular}

Table 7: $\quad$ Factsheet information for the indicator 5.

\begin{tabular}{ll}
\hline \multicolumn{2}{c}{ I5: LEVEL OF GENERATION OF PHYTOSANITARY PACKAGING WASTE } \\
\hline Description & $\begin{array}{l}\text { This indicator assesses the generation of phytosanitary packaging waste through } \\
\text { the use of ecologic farming practices. }\end{array}$ \\
\hline & $\begin{array}{l}\text { Plant protection products contain substances classified as dangerous and it is } \\
\text { necessary to take appropriate security measures and compliance with the doses } \\
\text { and times indicated on the container security. The packaging waste obtained is } \\
\text { usually impregnated with traces of the product. An ecological agricultural } \\
\text { practice avoids the use of these products, so that through the hectares for this } \\
\text { agriculture, the reduction of the packaging generation can be estimated. }\end{array}$ \\
$\begin{array}{ll}\text { relevance } \\
\text { Ministry of Environment (Spain) }\end{array}$ \\
\hline $\begin{array}{l}\text { Data sources } \\
\text { Methodology of }\end{array}$ & $\begin{array}{l}\text { The indicator is calculated as the number of hectares under organic farming and } \\
\text { integrated production in Cantabria compared to total hectares of existing farms. }\end{array}$ \\
\hline
\end{tabular}

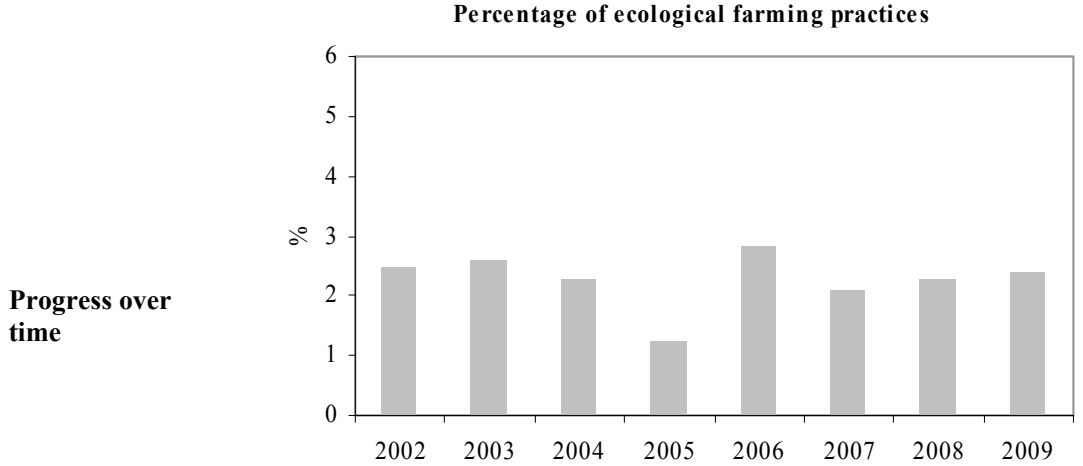

Cantabria agriculture is mainly oriented towards livestock, with a low presence of agriculture. For this reason the use of pesticides is much lower than in other parts of Spain and is very focused on the use of herbicides.

The area used to ecological practices is still small, with a rate of $2.5 \%$. As this data increases, the amount of generated packaging will be reduced.

Interpretation of results 
Table 8: $\quad$ Factsheet information for the indicator 6.

\begin{tabular}{|c|c|}
\hline \multicolumn{2}{|r|}{ I6: RATE OF USEFUL LAND TO REUSE THE MANURE } \\
\hline Description & $\begin{array}{l}\text { This indicator looks at the amount of agricultural area that would be necessary } \\
\text { to reuse the manure generated by livestock without causing environmental } \\
\text { damage. }\end{array}$ \\
\hline $\begin{array}{l}\text { Environmental } \\
\text { relevance }\end{array}$ & $\begin{array}{l}\text { Farms have traditionally used manure as agricultural fertilizer due to its high } \\
\text { nutrient content. This management, mainly due to nitrate content of manure, } \\
\text { contaminated soil on many occasions. It is a valid practice for small farms that } \\
\text { have no surface problems using manure, but not for intensive and large farms } \\
\text { that have not enough area for this. } \\
\text { Therefore, a controlled management of this waste is required to prevent } \\
\text { environmental degradation and reduce dumping waste without any control. } \\
\text { For that, it is required to study the availability of land for livestock-farm } \\
\text { manure, being necessary to ensure correct application rates to avoid soil } \\
\text { contamination. }\end{array}$ \\
\hline Data sources & Ministry of Environment (Spain) \\
\hline $\begin{array}{l}\text { Methodology } \\
\text { of calculation }\end{array}$ & $\begin{array}{l}\text { For its calculation, the data of available land is taken from the Yearbook of } \\
\text { Statistics, Ministry of Environment. } \\
\text { Also, the area required to take the manure is calculated from the number of } \\
\text { cattle (also included in the Yearbook of Statistics of the Ministry of } \\
\text { Environment), by charging rates of manure generation and content nitrogen. } \\
\text { Once the genenerated amount of nitrogen is calculated, with the nitrogen } \\
\text { application limit defined (by Directive } 91 / 676 / E E C \text { on } 170 \mathrm{kgN} / \mathrm{ha} / \text { year), } \\
\text { the amount of required area that would be needed in the region to absorb the } \\
\text { amount of manure generated is calculated. }\end{array}$ \\
\hline
\end{tabular}

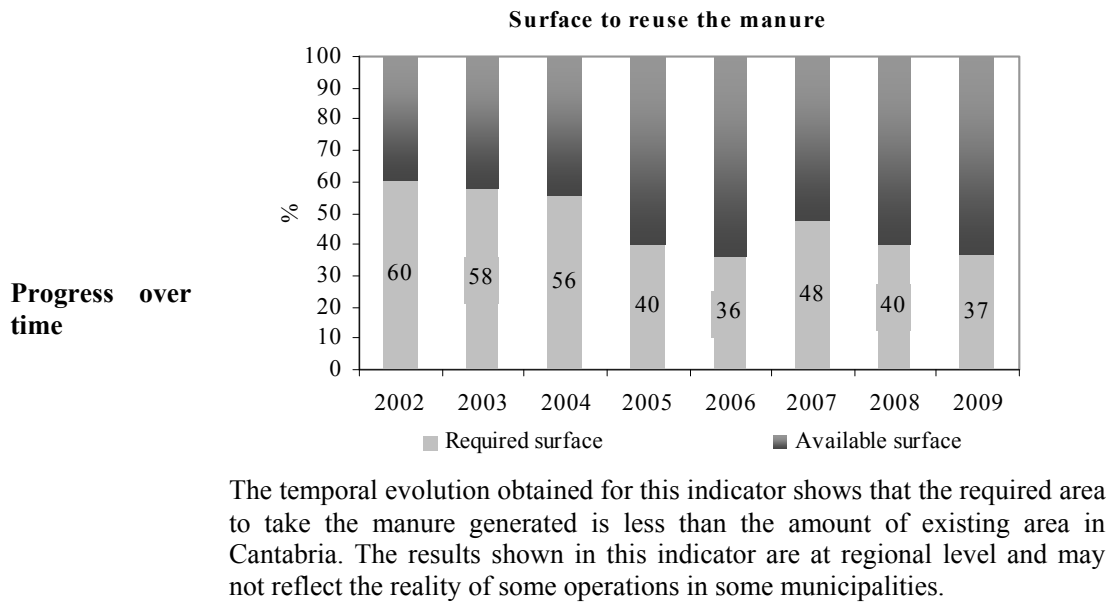

\section{Interpretation of results}

Once developed the most promising indicators, it is necessary to conduct a SWOT analysis to study the current status of each one (Table 10). 
Table 9: $\quad$ Factsheet information for the indicator 9.

I9: RATE OF RECOVERY OF PHYTOSANITARY PACKAGING WASTE
$\begin{gathered}\text { This indicator measures the amount of packaging waste recovered compared } \\ \text { to the total packaging waste generated in Cantabria. }\end{gathered}$

to the total packaging waste generated in Cantabria.

Environmental relevance

\begin{tabular}{lrl} 
Data sources & product packaging and unopened containers removed. \\
\hline $\begin{array}{l}\text { Methodology } \\
\text { of calculation }\end{array}$ & The indicator is derived by dividing the amount of packaging recovered and \\
the amount of packaging consumed by farmers.
\end{tabular}

As for the management of packaging of plant protection products is different depending on their content, distinguishing the empty containers that contain product packaging and unopened containers removed.

Table 10: $\quad$ SWOT Analysis.

\begin{tabular}{|c|c|c|c|c|c|c|c|c|c|c|c|c|}
\hline \multirow{2}{*}{\multicolumn{2}{|c|}{ SWOT ANALYSIS }} & \multicolumn{11}{|c|}{ Indicator } \\
\hline & & 1 & 2 & 3 & 4 & 5 & 6 & 7 & 8 & 9 & 10 & 11 \\
\hline \multirow{2}{*}{$\underline{\underline{\text { EXTERN }}}$} & $\begin{array}{c}\text { Management Model } \\
\text { Established }\end{array}$ & - & - & - & $\mathrm{T}$ & - & $\mathrm{T}$ & $\mathrm{T}$ & $\mathrm{T}$ & $\mathrm{O}$ & $\mathrm{T}$ & $\mathrm{T}$ \\
\hline & $\begin{array}{c}\text { Integrated Management } \\
\text { Systems }\end{array}$ & - & - & - & $\mathrm{O}$ & $\mathrm{O}$ & $\mathrm{T}$ & $\mathrm{T}$ & - & $\mathrm{O}$ & $\mathrm{T}$ & $\mathrm{T}$ \\
\hline \multirow{5}{*}{$\begin{array}{l}\text { Opportunities } \\
\quad(\mathbf{O}) \\
\text { Threats ( } \mathbf{T})\end{array}$} & $\begin{array}{c}\text { Existing Infrastructure } \\
\text { (Recycling or treatment } \\
\text { plants) }\end{array}$ & - & - & - & $\mathrm{T}$ & - & $\mathrm{T}$ & $\mathrm{T}$ & - & $\mathrm{O}$ & - & $\mathrm{T}$ \\
\hline & Collection Points & - & - & - & $\mathrm{T}$ & & $\mathrm{T}$ & - & - & $\mathrm{T}$ & $\mathrm{T}$ & $\mathrm{T}$ \\
\hline & Subsidies/ Economic Aids & $\mathrm{O}$ & - & $\mathrm{O}$ & - & $\mathrm{O}$ & $\mathrm{O}$ & $\mathrm{T}$ & - & - & $\mathrm{O}$ & $\mathrm{O}$ \\
\hline & Courses/ Training Progams & - & $\mathrm{O}$ & $\mathrm{T}$ & - & $\mathrm{T}$ & $\mathrm{O}$ & $\mathrm{T}$ & - & - & $\mathrm{T}$ & $\mathrm{T}$ \\
\hline & Campaigns & - & $\mathrm{O}$ & $\mathrm{T}$ & $\mathrm{T}$ & $\mathrm{T}$ & $\mathrm{O}$ & $\mathrm{T}$ & - & - & $\mathrm{T}$ & $\mathrm{T}$ \\
\hline \multirow{4}{*}{$\begin{array}{c}\text { INTERN } \\
\text { ANALYSIS } \\
\text { Strengths (S) } \\
\text { Weakness }(\mathbf{W})\end{array}$} & Specific Legislation & $\mathrm{W}$ & - & - & $\mathrm{W}$ & $\mathrm{W}$ & $\mathrm{W}$ & $\mathrm{W}$ & $\mathrm{W}$ & $\mathrm{W}$ & $\mathrm{W}$ & $\mathrm{W}$ \\
\hline & Specific Waste Plan & $\mathrm{W}$ & - & - & W & $\mathrm{W}$ & $\mathrm{W}$ & $\mathrm{W}$ & - & $\mathrm{W}$ & $\mathrm{W}$ & W \\
\hline & Autonomic Register & $\mathrm{W}$ & $\mathrm{W}$ & $\mathrm{W}$ & - & $\mathrm{S}$ & $\mathrm{S}$ & $\mathrm{W}$ & $\mathrm{W}$ & $\mathrm{S}$ & $\mathrm{W}$ & $\mathrm{W}$ \\
\hline & Particular Studies & $\mathrm{S}$ & - & - & - & - & $\mathrm{S}$ & $\mathrm{S}$ & - & - & - & - \\
\hline
\end{tabular}


The analysis SWOT shows that there are more Threats (T) and Weakness (W) than Opportunities $(\mathrm{O})$ and Strengths $(\mathrm{S})$. In the future the lack of data for developing the indicators will be improved due to different ongoing activities: integrated management systems implementation, economic aids, educational campaigns and courses and particular studies.

\section{Conclusions}

In order to assess the situation of the waste produced by the primary sector in Cantabria, a set of indicators has been developed for evaluating the proposed objectives on the Primary Sector Regional Waste Plan 2010-2014. The methodology for the development of indicators consists of five stages, including synthesis, development, application, interpretation and SWOT analysis. As a result, eleven indicators related to flows of waste like manure, biodegradable plastics used in agriculture, phytosanitary packaging, residual forest biomass, and food industry have been obtained.

After a specific analysis of sources of information some problems have been found. There are many statistics about agriculture and agri-environmental indicators and a lack of regional data about waste streams, although some punctual studies have been obtained. The availability of data for developing indicators has been evaluated through scoring method using different characteristics of indicators as relevance, credibility, functionality, quantifiable and comparability as criteria. The results obtained show that only four indicators obtain more than 10 points over 16 in the evaluation. The indicators developed are: (i) level of use of biodegradable plastics; (ii) level of generation of phytosanitary packaging waste; (iii) rate of useful land to reuse the manure; and (iv) rate of recovery of phytosanitary packaging waste. The SWOT analysis for each indicator shows the current situation and defines the required changes and modifications to comply with the new possibilities.

Therefore it can conclude that the applied methodology is a tool for decisionmaking about Primary Sector Regional Waste Plan and can be useful to improve the data and sources of the indicators.

\section{References}

[1] BOC, Boletín Oficial de Cantabria, Decreto 15/2010, de 4 de marzo, por el que se aprueban los Planes Sectoriales de Residuos, (66), pp.12005-12198, 2010.

[2] Aguirre, M.A., Los sistemas de indicadores ambientales y su papel en la información e integración del medio ambiente. Libro de ponencias del I Congreso de Ingeniería Civil, Territorio y Medio Ambiente, Madrid, 2002.

[3] Smeets, E. \& Weterings, R., (eds). Environmental indicators: typology and overview. European Environmental Agency, Technical report no 25, p 19, 1999. 
[4] Cifrian, E., Coz, A., Viguri, J \& Andrés, A., Indicators for valorisation of Municipal Solid Waste and Special Waste. Waste Biomass Valor, (1), pp. 479-486, 2010

[5] Niemejer, D. \& Groot, R., A conceptual Framework for selecting environmental indicator sets. Ecological Indicators, (8), pp.14-25, 2008

[6] European Environment Agency, The IRENA indicator report: Agriculture and environment in EU-15, 2005

[7] Yli-Viikari, A., Evaluating agri-environmental indicators (AEIs) - Use and limitations of international indicators at national level. Ecological Indicators (7), pp.150-163, 2007

[8] Yang, Y., SWOT-TOPSIS Integration Method for Strategic Decision, International Conference on E-Business and E-Government, 2010.

[9] EEA, European Environment Agency, www.eea.europa.eu/es

[10] OECD, Organisation for Economic Co-operation and Development, www.oecd.org

[11] INE, Instituto Nacional de Estadística, www.ine.es

[12] MMA, Ministerio de Medio Ambiente y Medio Rural y Marino, www.marm.es

[13] SIG, Sigfito Agroenvases, http://www.sigfito.es

[14] ICANE, Instituto Cántabro de Estadística, www.icane.es

[15] CIFA, Centro de Investigación y Formación Agrarias, www.cifacantabria.org

[16] Kurtz, J., Jackson, L.E. \& Fisher, W.S., Strategies for evaluating indicators based on guidelines from the Environmental Protection Agency's Office of Research and Development. Ecological Indicators, (1), pp. 49-60, 2001. 